\title{
HEALTH ASPECTS OF INNOVATION IN MODERN SOCIETY
}

Kolomin W, Kudryasheva IA, Devrishov RD雨, Khorosheva IV, Gololobov MI, Khabchiev RK, Filyaev VN

Astrakhan State Medical University, Astrakhan, Russia

Wide use of computers, information and communication technologies and gadgets in industry and society unlocks creativity, refines logic, stimulates analytical and research skills, makes work much easier, and allows many types of activities to be performed remotely. But despite their indisputable advantages, information technologies have a downside. The negative impact of computers and electronic gadgets on the cognitive, emotional and mental states, the gastrointestinal tract, vision and the musculoskeletal system have been proved. Children are particularly sensitive to the negative effects of IT. This study provides concise information on some IT-associated health conditions (IT-associated morbidity) and proposes some measure to minimize the negative effects of IT on children's health.

Keywords: hygiene, information and communication technology, IT-associated pediatric morbidity, prevention

Author contributions: Kolomin W- study concept and design, data acquisition, statistical analysis, manuscript preparation; Kudryasheva IA - editing; Devrishov RD - data acquisition and processing, manuscript preparation; Khorosheva IV — data acquisition, statistical analysis; Gololobov MI — editing; Khabchiev RK — data acquisition; Filyaev VN — editing

$\triangle$ Correspondence should be addressed: Ruslan Devrishov Bakinskaya 121, Astrakhan, 414000, 89608587176, memorydb@yandex.ru

Received: 12.04.2021 Accepted: 14.05.2021 Published online:: 30.06.2021

DOI: $10.24075 /$ rbh.2021.013

Key words: hygiene, information and communication technologies, IT associated morbidity in the child population, prevention.

\section{ГИГИЕНИЧЕСКИЕ АСПЕКТЫ ИННОВАЦИОННЫХ ПРОЦЕССОВ В СОВРЕМЕННОМ ОБЩЕСТВЕ}

В. В. Коломин, И. А. Кудряшева, Р. Д. Девришов ${ }^{\star}$ И. В. Хорошева, М. И. Гололобов, Р. К. Хабчиев, В. Н. Филяев

Астраханский государственный медицинский университет, г. Астрахань, Россия

Широкое применение компьютерной техники, информационно-коммуникационных устройств и гаджетов во всех сферах производственной и общественной жизни способствует раскрытию творческого потенциала человека, положительно влияет на совершенствование логического мышления, вырабатывание аналитических и исследовательских навыков, а в профессиональной деятельности значительно облегчает трудовой процесс, позволяет осуществлять многие операции удаленно. Вместе с тем, при наличии несомненных положительных аспектов использования информационных технологий, их применение имеет и отрицательную сторону. Доказательно установлено негативное влияние компьютерной техники и электронных гаджетов на когнитивную, психо-эмоциональную и физиологическую сферы человека, а также их участие в развитии патологий органов зрения и желудочно-кишечного тракта, опорно-двигательного аппарата. Наиболее восприимчив к негативному воздействию объектов применения информационных технологий (ІТ объектов) организм ребенка. В работе представлена краткая информация о патологических изменениях в организме детей и подростков, ассоциированных воздействием информационных технологий и IT объектов (IT ассоциированная заболеваемость). Предложены возможные мероприятия по минимизации негативного влияния ІT объектов на здоровье ребенка.

Ключевые слова: гигиена, информационно-коммуникационные технологии, IT ассоциированная заболеваемость детского населения, профилактика.

Вклад авторов: В. В. Коломин - концепция и дизайн исследования, сбор, статистическая обработка данных, написание и редактирование текста; И. А. Кудряшева - редактирование текста; Р. Д. Девришов - сбор и обработка материала, написание текста И. В. Хорошева - сбор материала, статистическая обработка данных М. И. Гололобов - редактирование текста Р. К. Хабчиев - сбор материала В. Н. Филяев - редактирование текста

$\triangle$ Для корреспонденции: Руслан Девришович Девришов

ул. Бакинская, д. 121, г. Астрахань, 414000; memorydb@yandex.ru

Поступила: 12.04.2021 Статья принята к печати: 14.05.2021 Опубликована онлайн: 30.06.202

DOI: $10.24075 /$ rbh.2021.013

Today, society is faced with a variety of new environmental risk factors whose impact on pediatric health is yet to be explored. Those include information technologies (IT) and IT devices that are widely used by children and adolescents and have become indispensable to their socialization and the learning process.

Russia makes significant effort to prevent the negative impact of IT and IT devices on public health. The approach to creating healthy conditions for child development is systemic and reflects the principles outlined in the Information Safety Framework for Children [1] and the roadmap for its implementation under the Decade of Child Welfare (2018-2027) project [2] declared by the Order 240 of the President of Russia issued on May 29, 2017. Importantly, the sanitary aspects of using IT and IT devices by children and adolescents are regulated by the healthcare legislation of the Russian Federation [3].
At the same time, despite great effort, the problem of ITassociated morbidity among children and adolescents remains a pressing concern.

The aim of the study was to propose measures for reducing IT-associated morbidity.

\section{METHODS}

The study included data collected in public schools, gymnasiums and lyceums in 4 different districts of Astrakhan region. The data collected in 2011-2018 were provided by the Federal Research Institute for Health Organization and Informatics of Ministry of Health of the Russian Federation and the Department of Analysis, Forecasts, Public Healthcare Medical Science Development of the Ministry of Healthcare 
of the Russian Federation; the data also included results of integral health assessment (medical examinations, surveys) conducted among junior to high schoolers aged 7 to 17 years.

Statistical analysis was performed using a linear regression method in Statgraphics and Microsoft Excel; Pearson's correlation coefficient $(r)$ was calculated to measure the strength and direction of possible associations between the variables; we also used the coefficient of determination (R2). The significance threshold was set at $p<0.05$.

\section{RESULTS}

Children and adolescents develop ophthalmic diseases amidst increasing exposure to a variety of environmental factors, including IT devices.

Studies involving high school students of Moscow, Moscow region and Arkhangelsk have established associations between the use of IT devices and ocular morbidity. The risk varies from moderate to high, depending on the frequency of using the computer and laptop [4]. Strong correlations (Pearson's correlation coefficient $0.75, p<0.001$ ) between moderate/severe myopia and the frequency of using the computer and laptop among high school students of Moscow were established by the researchers from Pirogov Russian National Research Medical University. Functional eye disorders were detected in $67.2 \%$ of high school students and $19.0 \%$ of second year university students; $8.2 \%$ of schoolers and $53.6 \%$ of university students were found to have chronic ocular disorders (moderate and severe myopia) [5].

These results are consistent with the findings of our previous work (Assessment of learning environment and health of public school students of Astrakhan region), which reported a growing negative effect of IT devices on the visual system of children in the past years. Moderate myopia was diagnosed in $14.0 \%$ of $9^{\text {th }}$ grade students and $21.0 \%$ of $11^{\text {th }}$ grade students. The survey revealed that the proportion of children using IT devices over $2-3 \mathrm{~h}$ a day was increasing from $30.0 \%$ in primary school to $60.0 \%$ in middle and $70.0 \%$ in high school [6].

Multiple studies conducted in Russia and abroad demonstrate that IT devices are becoming a new etiological factor contributing to ophthalmic diseases. However, the effects of IT devices are indirect for many other conditions. IT devices are not a direct driver of musculoskeletal (MS) and gastrointestinal (GI) disorders. But the confirmed associations between the use of IT devices and $\mathrm{MS} / \mathrm{Gl}$ diseases in the pediatric population suggest that these conditions could be classified as IT-associated. This has been confirmed by the studies conducted in a number of Russian cities (Moscow, Arkhangelsk, Nizhny Novgorod) establishing the risk of MS and Gl diseases due to the use of computers, laptops and tablets $[4,5,7,8,9,10,11]$.

IT-associated MS and Gl disorders are largely the result of excessive or inadequate use of IT devices by children and adolescents, which disrupts their daily routine, eating schedule, leads to the lack of movement and an unhealthy lifestyle in general. According to studies conducted in Arkhangelsk, the irrational use of IT devices was a disruption to the eating schedule for $29.2 \%$ of high school students and interfered with the normal sleep-wake schedule in $41.6 \%$ of teenagers
[7]. According to a report from Astrakhan, $20.0 \%$ of primary schoolers and $65.0 \%$ of high school students spent less than $1 \mathrm{~h}$ outdoors during the day [6].

Low levels of physical activity in combination with an awkward posture while working with an IT device contribute to musculoskeletal system disorders. The analysis of child morbidity revealed that the proportion of children with MS disorders rises from $12.0 \%$ in primary school to $26.4 \%$ in high school [6].

The rise in the prevalence of ocular pathology, gastrointestinal and musculoskeletal disorders can be explained not only by the increasing exposure to environmental factors but also by the low effectiveness of health-saving technologies due to the absence of systemic approach. Thus, $42.9 \%$ of schools use health-saving technologies to prevent ocular and gastrointestinal diseases, whereas $57.1 \%$ of schools use these technologies to prevent musculoskeletal disorders.

\section{DISCUSSION}

Based on the results of the study, we hypothesize that the low effectiveness of prevention measures implemented by the state might be due to:

- out-of-school factors (including information and communication technologies used in the learning process);

- the lack of systemic complex approach to the application of health-saving technologies, which are used without due consideration of their effects on the health of children.

Besides, the positive effect of prevention measures can be neutralized by irrational leisure time planning for children, teenagers and the whole family and the absence of systemic parental control over information content. Parental control unsupported by rational time planning for the whole family is not effective. Studies conducted in Arkhangelsk and Moscow demonstrate that the systemic approach to the problem results in a decrease in the proportion of children who use computer over 3 hours a day from $70.5 \%$ to $13.3 \%$ but their level of physical activity remains the same (27.6\% vs $27.3 \%)$ [7].

\section{CONCLUSIONS}

Measures implemented by the state do not radically prevent the negative impact of IT on the health of children.

The solution to the problem of pediatric and teenage health and prevention of IT-associated morbidity lies in the complex approach, which includes the use of health-saving technologies. Indeed, it is important to follow the guidelines on the duration and other aspects of using the computer by the child. No less important is quality leisure time, regular physical and intellectual activity, daily routines and sleep-wake schedule.

Prevention of IT-associated conditions could be more effective if it accounted for children's hobbies. Here, health education plays a significant role and its effectiveness is largely determined by the methods used to instill the idea of healthy lifestyle. Such education should be engaging and comprehensible.

\section{References}

1. Koncepcija informacionnoj bezopasnosti detej. Rasporjazhenie Pravitel'stva RF ot 2 dekabrja 2015 g. № 2471-r. Russian.

2. Plan osnovnyh meroprijatij do 2020 g., provodimyh v ramkah Desjatiletija detstva (s izmenenijami i dopolnenijami).

Rasporjazhenie Pravitel'stva RF ot 6 ijulja 2018 g. № 1375-r. Russian.

3. SP 2.4.3648-20. Sanitarno-jepidemiologicheskie trebovanija k organizacijam vospitanija i obuchenija, otdyha i ozdorovlenija 
detej i molodezhi. Postanovlenie Glavnogo gosudarstvennogo sanitarnogo vracha Rossijskoj Federacii ot 28 sentjabrja 2020 goda № 28. Russian.

4. Milushkina OYu, Skoblina NA, Markelova SV, Tatarinchik AA, Bokareva NA, Fedotov DM. Assessing health risks for schoolchildren and students caused by exposure to educational and entertaining information technologies. Health Risk Analysis 2019; 3: 135-143. DOI: 10.21668/health.risk/2019.3.16.eng. Russian.

5. Svetlana V. Markelova. The role of printed and electronic publications in development of vision disorders. Fundamental and Clinical Medicine. 2019; 4 (4): 97-104. https://doi. org/10.23946/2500-0764-2019-4-4-97-104. Russian.

6. Devrishov RD, Kolomin VV, Filyaev VN, Kudryasheva IA. Gigienicheskie aspekty vozdejstviya faktorov sredy obitaniya na formirovanie zdorov'ya uchashchihsya. Rossijskij mediko-biologicheskij vestnik imeni akademika I.P. Pavlova. 2019; 27(4):530-535. https://doi.org/10.23888/ PAVLOVJ2019274530-535. Russian.

7. Vasil'ev VV, Perekusihin MV, Korochkina Yu V. Vliyanie ekologicheskih i social'no-gigienicheskih faktorov na sostoyanie

\section{Литература}

1. Концепция инсрормационной безопасности детей. Распоряжение Правительства РФ от 2 декабря 2015 г. № 2471-р.

2. План основных мероприятий до 2020 г., проводимых в рамках Десятилетия детства (с изменениями и дополнениями). Распоряжение Правительства РФ от 6 июля 2018 г. № 1375-р.

3. СП 2.4.3648-20. Санитарно-эпидемиологические требования к организациям воспитания и обучения, отдыха и оздоровления детей и молодежи. Постановление Главного государственного санитарного врача Российской Федерации от 28 сентября 2020 года № 28 .

4. Милушкина О.Ю., Скоблина Н.А., Маркелова С.В., Татаринчик А.А., Бокарева Н.А., Федотов Д.М. Оценка рисков здоровью школьников и студентов при воздействии обучающих и досуговых информационно-коммуникационных технологий. Анализ риска здоровью. 2019; 3: 135-143.

5. Маркелова С.В. Роль печатных и электронных изданий в формировании функциональных нарушений и хронических заболеваний органа зрения обучающихся. Фундаментальная и клиническая медицина. 2019;4(4): 97-104.

6. Девришов Р.Д., Коломин В.В., Филяев В.Н., Кудряшева И.А. Гигиенические аспекты воздействия факторов среды обитания на формирование здоровья учащихся. Российский медико-биологический вестник имени академика И.П. Павлова. 2019;27(4):530-535. https://doi. org/10.23888/PAVLOVJ2019274530-535 zdorov'ya detej shkol'nogo vozrasta. Gigiena i sanitariya. 2016; 95(8):760-764. http://doi: 10.18821/0016-9900-2016-95-8760-764. Russian.

8. Makarova LP, Bujnov LG, Plahov NN. Gigienicheskie osnovy formirovaniya kul'tury zdorovogo obraza zhizni shkol'nikov. Gigiena i sanitariya. 2017; 96(5):463-466. http://dx.doi. org/10.1882/0016-9900-2017-96-5-463-466. Russian.

9. Shcherbakova NB. Strategicheskie osnovy deyatel'nosti roditelej poorganizacii raboty shkol'nikov na komp'yutere $v$ domashnih usloviyah. Vestnik Moskovskogo gosudarstvennogo oblastnogo universiteta. Seriya: Pedagogika. 2018; (2): 78-88. DOI: 10.18384/2310-7219-2018-2-78-88. Russian.

10. Ivanova IE, Rodionov VA. Povyshenie effektivnosti prakticheskoj realizacii proekta «shkol'naya medicina" $v$ sovremennyh usloviyah. Prakticheskaya medicina. 2019; 17(5):107-109. http://doi: 10.32000/2072-1757-2019-5-107-109. Russian.

11. Prahin El, Gurov VA, Ponomareva EV. Psihosomaticheskie osobennosti detej $\vee$ mediko-pedagogicheskom monitoring zdorov'eformiruyushchej deyatel'nosti shkol. Gigiena i sanitariya. 2018; 97(7):635-641. http://dx.doi.org/10.18821/0016-99002018-97-7-635-641. Russian.

7. Васильев В.В., Перекусихин М.В., Корочкина Ю.В. Влияние экологических и социально-гигиенических факторов на состояние здоровья детей школьного возраста. Гигиена и санитария. 2016; 95(8):760-764. http://doi: 10.18821/00169900-2016-95-8-760-764

8. Макарова Л.П., Буйнов Л.Г., Плахов Н.Н. Гигиенические основы формирования культуры здорового образа жизни школьников. Гигиена и санитария. 2017; 96(5):463-466. http:// dx.doi.org/10.1882/0016-9900-2017-96-5-463-466

9. Щербакова Н.Б. Стратегические основы деятельности родителей по организации работы школьников на компьютере в домашних условиях. Вестник Московского государственного областного университета. Серия: Педагогика. 2018; 2:78-88. DOI: 10.18384/2310-7219-20182-78-88.

10. Иванова И.Е., Родионов В.А. Повышение эффективности практической реализации проекта «Школьная медицина» в современных условиях. Практическая медицина. 2019; 17(5):107-109. http://doi: 10.32000/2072-1757-2019-5-107109

11. Прахин Е.И., Гуров В.А., Пономарева Э.В. Психосоматические особенности детей в медико-педагогическом мониторинге здоровьеформирующей деятельности школ. Гигиена и санитария. 2018; 97(7):635-641. http://dx.doi. org/10.18821/0016-9900-2018-97-7-635-641 